\title{
Fiandong Shi
}

\section{Foreign Direct Investment in Ghina and the Sino-US Trade Imbalance}

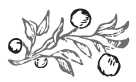

\section{Summary}

As economic globalization is deepening, a new international division of labor emerges, which is, to a large extent, realized in the form of FDI. Sino-US trade is in the state of fast development, and foreign direct investment in China also goes through large-scale expansion in the meantime. With its huge market potential, broad development prospects and increasingly improved investment environment, China has attracted an increasing number of foreign investors to invest in China, thus China is gradually becoming a great power utilizing foreign investment. Foreign-funded enterprises in China play a significant role in the import and export trade between China and the United States and the development of Sino-US trade. The rapid growth of China-US trade is largely benefited by the rapid development of foreignfunded enterprises in China. In the long run, foreign direct investment in China has a great impact on Sino-US import and export trade. In this paper, the correlation between the volumes of foreign investments in China during the period between 1983-2019 and the Sino-US import and export trade is analyzed, and based on the co-integration relationship between foreign direct investment in China and the Sino-US import and export trade, it comes to a conclusion that foreign direct investment in China plays a catalytic role in both import and export trade between China and the United States, that is, foreign direct investment has a stimulating effect on Sino-US import and export trade, resulting in China's ever-expanding trade surplus with the United States.

Journal of Economic Literature (JEL) codes: F10

Keywords: Foreign Direct Investment in China, Sino-US Trade, Balance of Trade

Jiandong Shi, PhD student, National University of Public Service, Budapest (shijiandong1101@qq.com). 


\section{INTRODUGTION}

The rapid advancement of the Sino-US economic relationship has always been regarded as one of the most striking features of economic globalization since China's accession to the WTO. Thus, policy makers and academic circles of the two countries have been paying close attention to this relationship. For quite a long time, American enterprises have been engaged in investing large amounts directly in China, while Chinese enterprises' investment in the United States has always been a weak point, that is, there is a significant asymmetry in the bilateral direct investment relationship between China and the United States. However, "investment is a big issue in the Sino-US relationship", which is "even more important than bilateral trade". This is not only because the relationship between bilateral direct investment and trade is mutually reinforcing, but also helps to alleviate the trade imbalance persisting in the bilateral trade relationship between China and the United States for a long time, as well as the trade conflicts arising from it. The China-US trade friction has appeared frequently since the 1990s, and the major cause is the China-US trade imbalance. In 2018, the total value of the China-US bilateral trade in imports and exports was US\$633.52 billion, and China's trade surplus with the US amounted to US\$323.32 billion (Phoenix Finance, 2019). The protectionism policies of selective investment adopted by the US government since the Trump administration, which are mainly aimed at Chinese enterprises, fully demonstrate the significance of conducting in-depth studies on the impact of foreign direct investment in China on the Sino-US trade imbalance.

There have been many scholars analyzing the Sino-US trade imbalance from the perspective of US direct investment in China, and it is generally believed that the direct investment of the United States in China is the main cause of the Sino-US trade imbalance, based on which the purpose of this paper is to propose measures to alleviate the Sino-US trade imbalance. Is there any relationship between investment by other countries and the Sino-US trade imbalance? The relevant research on this issue is not perfect. Therefore, this paper has conducted in-depth research on what has brought about such a large trade gap between China and the United States. Based on this, the paper further analyzes and explores the Sino-US trade imbalance in different ways from the perspective of foreign direct investment in China, so as to provide a factual basis for further understanding this issue.

The target groups of this paper are the readers and researchers who have interest in trade imbalance, the Sino-US trade and foreign direct investment, as well as government departments related to Sino-US trade and the employees of export businesses. This topic analyzes the Sino-US trade imbalance from the perspective of the foreign direct investment in China, identifies the most important reasons for the Sino-US trade imbalance, thereby providing some new research results for the related work of government administration and export enterprises, and contributing to the important practical significance of adjusting the Sino-US trade aggregate imbalance, dissolving the Sino-US trade friction, promoting the development of Sino-US trade and promoting the global economic balance. 
The theoretical significance of this paper mainly lies in the fact that there are endless pieces of literature addressing the Sino-US trade imbalance, but most scholars make studies from the perspective of the RMB exchange rate, US direct investment in China and the control over US export to China. Chen (2006), Fu (2008 a,b) et al. argued that the Sino-US trade imbalance is, to a large extent, caused and expanded by US direct investment in China. Then Wang and others Qu (2006), Li (2006) Gao (2009) respectively used econometric analysis to show that the trade imbalance between China and the United States has no direct relationship with the RMB exchange rate, and came to the conclusion that the RMB appreciation can only alleviate the surplus to some extent in the short term, but has a weak effect in the long run. From the perspective of foreign direct investment in China, this topic discusses the influence of foreign direct investment in China on Sino-US trade, analyzes the root causes of the Sino-US trade imbalance, and provides a theoretical basis for the alleviation of the Sino-US trade imbalance and the formulation of Sino-US trade policies, so as to further carry forward the study of Sino-US trade. Meanwhile, the research perspective of this topic provides a good basis for the research of other related issues.

\section{TRADE AND FOREIGN DIREGT INVESTMENT}

A substitution relationship lies between trade and direct investment, which is reflected in the fact that the international capital flow originates from the obstacles to international trade, while international trade arises from the obstacles to capital flow. R. A. Mundell was the first to study the substitution relationship between the two. Based on the analytical framework of trade theory $\mathrm{H}-\mathrm{O}$, he studied the substitution relationship between international trade and FDI by means of a standard model. Through research, R. A. Mundell (1957) found that if there are factors hindering free trade, such as international trade barriers, and assuming that corporations can always make transnational investments along the track of the Rybczynski line, such investment can make cost conversion with a relatively low factor or completely replace the transnational commodity trade in an efficient way, which is relatively optimum. Such alternative theory well explains the international FDI phenomenon represented by American investment in Japan and Europe before the Second World War, but in the 1960s, the alternative theory of investment and trade encountered great challenges. Since the global economic integration develops, new vicissitudes have occurred in the relationship between trade and investment. Substitution is no longer an inevitable relationship between the two, and the relationship between investment and trade has shown obvious complementary or simulative relationships. Professor Kiyoshi Kojima (2000) rom Hitotsubashi University in Japan put forward the theory that there is mutual promotion between trade and investment, so as to explain the new phenomenon. By studying aggregate data, industry data and enterprise data, Lipsey and Weiss (2016) found that the export volume of a country has a significantly positive correlation with the sales volume of the subsidiary of its multinational corporation; that is, international direct investment and international trade are complementary. Wang and $\mathrm{Xu}(2003)$ tested the relationship of trade and investment between China and Japan by causality tests, signifying that there was a long-term complementary relationship betwe- 
en Japan's direct investment in China and Sino-Japan trade, and also a two-way causal relationship between FDI and the export of finished products, but FDI only had a one-way causal relationship for the import level. Moreover, they found that FDI and import trade had a short-term substitution effect. By studying the export share of American multinational corporations in different industries in the Canadian market and the production status of local subsidiaries, as well as tariff levels of different industries, Hurst in 1974 found that there was a substitution relationship between investment and trade, and he considered that tariff-led investment replaced trade, and the degree of substitution had a positive correlation with the tariff level of industries in this country.

\section{SINO-US TRADE IMBALANGE AND FOREIGN DIREGT INVESTMENT}

Zhu (2010) analyzed the general situation and obstacles of bilateral direct investment, and argued that expanding bilateral direct investment was of great significance, was one of the most effective ways to solve economic imbalance, which could not only solve the structure imbalance encountered in the development of the domestic economy in both countries, but also correct the imbalance of payments between China and the United States in the two effective ways of capital flow and trade flow. Fu, Zhu, by means of co-integration test and the error correction model, analyzed US direct investment in China and the Sino-US trade data, and they believed that Sino-US trade imbalance was largely caused and expanded by US direct investment in China, which mainly occurred from the processing trade of US investment in China and the reselling of manufactured products to America. Meanwhile, they considered that US direct investment in China not only affected the Sino-US trade with regard to total volume, but also affected the trade structure of China. Zhao (2009) proved, from the perspective of trade and investment integration, that there was a two-way causal relationship between US direct investment in China and China's exports to the US, that is, mutual influence. Tian (2005), on the basis of the co-integration theory, studied the long-term and short-term equilibrium relationship between US direct investment in China and Sino-US import and export trade, and concluded that incremental US investment in China would promote the rapid advancement of Sino-US trade. Bruke (2000) confirmed that the rapidly growing trade surplus between China and the United States was directly related to the growth in investment and the operation of multinational corporations in China. Lim and Moon (2001) proved that when developed countries invest in underdeveloped countries and the investment is newly established or it is a sunset industry in the home country, there is a positive correlation between outward foreign direct investment and trade. Liu, Wang and Wei (2001) adopted the panel data of 19 countries and China, and made an investigation in the causal relationship between FDI flowing into China and trade, revealing that import triggers FDI, while FDI triggers export, and there lies a complementary relationship.

McKinnon (2001) described two international supply channels and backflow channels of the dollar under the circumstances of the dollar standard system, and the cycle derived from the distribution of trade channels and the backflow of financial channels. That is, by purchasing commodities and services from peripheral countries, a great deal of US dollars are ex- 
ported, resulting in a huge trade deficit, and sending US dollars to the world. The peripheral countries then make US dollars flow back to the US by means of investment in US securities and FDI. The second form is financial channel distribution and trade channel backflow, that is, exporting US dollars by foreign investment by the United States, such as FDI, international credit and securities investment and other investment forms, or by means of foreign military assistance and gratuitous transfer payments; the United States makes US dollars flow back by exporting goods and services to peripheral countries. It is through these channels that the US trade deficit can exist for a long time.

Gourinchas and Rey (2014) constructed a long-term capital flow model to explain how the current "global imbalance" has been formed. The prediction of capital flow is divided into two parts in this model. First, the model demonstrates that capital would tend to flow from countries with lower self-sufficient earnings to countries with higher self-sufficient earnings. Second, the model identifies two determinants of a country's self-sufficient earnings: capital scarcity and long-term growth prospects, both of which are exogenous and country-specific. Based on the combination of both, the theory clearly indicates that developed economies are countries with a low self-sufficiency rate, and emerging economies are countries with a high self-sufficiency rate. Thus, capital should flow from better-off countries to "downstream" countries.

Jiwei Qian from the National University of Singapore argues that there are difficulties for China in the Sino-US trade war, such as a shock to the labor market, a high debt level and difficulty in gaining loans for private enterprises, the local debt-ridden situation, etc., which have made China launch a proactive fiscal and financial policy in 2018. Moreover, China has introduced the "Foreign Investment Law" to further open the market to foreign investors, improve the business environment and limit forced technology transfer, meanwhile "Made in China 2025" has been played down to a certain extent.

\section{Correlation test OF FOREIGN DiREGT INVESTMENT IN CHINA AND THE SINO-US TRADE IMBALANGE}

This paper uses empirical analysis to test the relationship between foreign direct investment in China and the Sino-US import and export trade from the perspective of time series. The main method adopted is the co-integration analysis, and Eviews 8.0 is used to analyze the relationship between foreign direct investment in China and the Sino-US import and export trade. An empirical test is conducted to verify the impact of foreign direct investment in China on the Sino-US trade and its degree.

\section{Data and variables}

Considering the availability of data, this paper selects the annual time series data from 1983 to 2019. The data are mainly from Wind and the National Bureau of Statistics of China, and obtained through sorting.

The variables involved in the test are as follows: FDI represents foreign direct investment 
in China, EX represents China's volume of exports to the US, IM represents China's volume of imports to the US, and TN represents the total volume of imports and exports between China and the US. To reduce the impact of heteroscedasticity fluctuations on the test, logarithmic transformation is performed on all the variables before the empirical test, and FDI, EX, IM and TN are respectively transformed into LNFDI, LNEX, LNIM and LNTN.

\section{Empirical test}

The test method used in this paper is the E-G two-step test. The specific steps are as follows: firstly, the Augmented Dickey-Fuller test (ADF) is used to determine the single integer order of variables. If the tested $\mathrm{ADF}$ absolute value is smaller than the absolute value of the critical value, then the variable is considered to be unstable, that is, there is a unit root. If the tested $\mathrm{ADF}$ absolute value is greater than the absolute value of the critical value, then the variable is considered to be stationary, that is, there is no unit root. If a group of time series has a longterm co-integration relationship, then the single order integers of all the variables should be identical. Then the ordinary least square (OLS) method is used to carry out co-integration regression of the variables. In the co-integration regression, it is necessary to test the error term of the model by a graphical method or the observation of the DW value to see whether there is auto-correlation. If there is auto-correlation, it should be corrected. Finally, the stationarity of the residual terms is tested, and the ADF test method is still used. If the residual sequence passes the ADF test, then there is a long-term stable relationship between the variables; if not, there is no long-term stable relationship between them.

All the tests involved in this paper are carried out in Eviews8.0.

\section{Stationarity test of variables}

The unit root test is generally used to test whether the sequence is stationary or not. There are three main test methods: the Augmented Dickey-Fuller test, the Dickey-Fuller Test with GLS test and the Philips-Perron test. The purpose of the stationary test is to avoid spurious regression. In this paper, the Augmented Dickey Fuller (ADF) unit root test is used to test the stationarity of each variable. The test principle is as follows:

In general, the following estimated regression equation is used to test whether the random sequence $\{y\}$ is stationary:

$$
\Delta y_{t}=\alpha_{0}+\gamma_{t}+(\beta-1) y_{t-1}+\sum_{i=1}^{k} \beta_{i} \Delta y_{t-i}+\mu_{t}
$$

When estimating the specific equation, if the test results of the constant term and trend term $\mathrm{Y}$ are not significant, they can be deleted; then the lag order can be determined by using the residual of the equation to meet the white-noise process, and the specific length of lag order can be determined by the AIC standard and the SG standard. In general, the lag order of the length in the optimal estimation equation should make the $\mathrm{AIC}$ and $\mathrm{SC}$ values mini- 
mum, and whether the random sequence $\{\mathrm{yt}\}$ is stationary is judged by the hypothesis test. The hypotheses are: $\mathrm{H} 0: \beta=1, \mathrm{H} 1: \beta<1$. The ADF value is the test value of $\beta$ in Equation 1 . If the $\mathrm{ADF}$ value of $\beta$ is greater than the critical value, hypothesis $\mathrm{H} 0$ is rejected, indicating that the sequence does not have a unit root, that is, the original sequence is stationary; On the contrary, if the ADF value of $\beta$ is smaller than the critical value, $\mathrm{Hl}$ is rejected, that is, the sequence has a unit root and is non-stationary. The ADF test results of the variables are shown in Table 1.

Table 1: Unit Root Test Results of Variables

\begin{tabular}{c|c|c|c|c|c}
\hline \multirow{2}{*}{ Variables } & \multirow{2}{*}{$\begin{array}{c}\text { ADF Test } \\
\text { Statistic }\end{array}$} & $\begin{array}{c}\mathbf{1} \% \text { critical } \\
\text { value }\end{array}$ & $\begin{array}{c}\mathbf{5 \%} \text { critical } \\
\text { value }\end{array}$ & $\begin{array}{c}\text { 10\% critical } \\
\text { value }\end{array}$ & \multirow{2}{*}{ Type Test } \\
\cline { 3 - 5 } & -1.670437 & -4.243644 & -3.544284 & -3.204699 & $(\mathrm{c}, \mathrm{t}, 1)$ \\
\hline LNFDI & -3.253053 & -3.632900 & -2.948404 & -2.612874 & $(\mathrm{c}, 0,0)$ \\
\hline$\Delta$ LNFDI & 0.432015 & -4.234972 & -3.540328 & -3.202445 & $(\mathrm{c}, \mathrm{t}, 0)$ \\
\hline LNEX & -3.823355 & -3.632900 & -2.948404 & -2.612874 & $(\mathrm{c}, 0,0)$ \\
\hline$\Delta$ LNEX & -1.300880 & -4.234972 & -3.540328 & -3.202445 & $(\mathrm{c}, \mathrm{t}, 0)$ \\
\hline LNIM & -5.217963 & -3.632900 & -2.948404 & -2.612874 & $(\mathrm{c}, 0,0)$ \\
\hline$\Delta \mathrm{LNIM}$ & 0.063250 & -4.234972 & -3.540328 & -3.202445 & $(\mathrm{c}, \mathrm{t}, 0)$ \\
\hline LNTN & -4.384112 & -3.632900 & -2.948404 & -2.612874 & $(\mathrm{c}, 0,0)$ \\
\hline$\Delta$ LNTN & &
\end{tabular}

Source: The author obtained by using Eviewes8.0 software analysis

Note: The test form $(c, t, k)$ represents the constant term, the trend term and the lag order in the ADF test.

According to the test results in Table 1, the ADF test values of LNFDI of foreign direct investment in China, LNEX of China's export volume to the US, LNIM of China's import volume from the US and LNTN of Sino-US total volume of imports and exports are respectively greater than $10 \%, 5 \%$ and $1 \%$. Hence, the four variables are non-stationary and have a unit root. The ADF test values of the first-order difference sequence $\square$ LNFDI of the variables are less than $10 \%$ and $5 \%$, and the ADF test values of $\square$ LNEX, $\square$ LNIM and $\square$ LNTN are respectively less than $10 \%, 5 \%$ and $1 \%$, indicating that the four variables are first-order difference stationary and have no unit root. Hence, the conditions for the co-integration test are met and a co-integration test can be carried out.

\section{Co-integration analysis}

According to the ADF test above, LNFDI and LNEX, LNFDI and LNIM, LNFDI and LNTN are all single integer series of the same order, so the least square method (OLS) can be used to estimate the correlation between LNFDI and LNEX, between LNFDI and LNIM and between LNFDI and LNTN, and obtain the residual terms. Then a unit root test (ADF) 
is carried out respectively on the residual terms. If the residual term is stationary, there is a co-integration relationship between foreign direct investment in China and Sino-US trade, that is, there is a long-term relationship between LNFDI and LNEX, between LNFDI and LNIM and between LNFDI and LNTN; if the residuals are non-stationary, there are no long-term co-integration relationships among the variables investigated.

Firstly, the model adopted in this paper is determined as follows:

$$
\begin{aligned}
& L \mathcal{N E X}=a_{1}+\beta_{1} L \mathcal{N} F D I+\varepsilon_{1} \\
& L N I M=a_{2}+\beta_{2} L N F D I+\varepsilon_{2} \\
& L \mathcal{N} T \mathcal{N}=a_{3}+\beta_{3} L \mathcal{N} F D I+\varepsilon_{3}
\end{aligned}
$$

Secondly, the equation of each model is estimated. The estimated results of LNFDI and LNEX, LNFDI and LNIM, LNFDI and LNTN by the OLS method are as below:

$$
\begin{aligned}
& \text { LNEX=-0.439076+1.166719LNFD } \\
& \quad(-1.337441)(20.90729) \\
& \mathrm{R}^{2}=0.925866 \quad \mathrm{~F}=437.1149 \text { D.W }=0.153323 \\
& \text { LNIM=1.136860+0.789179LNFDI } \\
& \quad(3.661053)(14.95104) \\
& \mathrm{R}^{2}=0.864621 \quad \mathrm{~F}=223.5335 \text { D.W }=0.153630 \\
& \mathrm{LNTN}=0.966869+1.005911 \mathrm{LNFDI} \\
& \quad(2.939528) \quad(17.99144) \\
& \mathrm{R}^{2}=0.902423 \quad \mathrm{~F}=323.6919 \text { D.W }=0.132052
\end{aligned}
$$

When the OLS method is used to estimate the long-term relationship of the three groups of variables, it is detected that the frequency of the residual variance curves of the three groups of variables passing through the zero curve is small, and the DW value is relatively low, hence, it can be determined that the above models all have autocorrelation. In this paper, the Cochrane-Orcutt iterative method is used to correct the positive autocorrelation, and the new estimating equation obtained after the correction is as follows:

$$
\begin{aligned}
& \mathrm{LNEX}=9.535277+0.370906 \mathrm{LNFDI}+0.981622 \mathrm{AR}(1) \\
& \text { (2.074618) (3.66628) (61.92663) } \\
& \mathrm{R}^{2}=0.996092 \quad \mathrm{~F}=4205.346 \text { D.W=1.642485 } \\
& \mathrm{LNIM}=6.887365+0.187364 \mathrm{LNFDI}+0.964490 \mathrm{AR}(1) \\
& \text { (3.465971) (1.428336) (38.50376) } \\
& \mathrm{R}^{2}=0.986546 \quad \mathrm{~F}=1209.938 \text { D.W=1.670853 }
\end{aligned}
$$




$$
\begin{array}{r}
\mathrm{LNTN}=9.304115+0.293007 \mathrm{LNFDI}+0.978004 \mathrm{AR}(1) \\
(2.735174)(2.843704) \quad(55.75281) \\
\mathrm{R}^{2}=0.994676 \quad \mathrm{~F}=3082.929 \mathrm{D} . \mathrm{W}=1.542044
\end{array}
$$

After the model correction, the frequency of the residual variance curves passing through the zero curves greatly increases, the D.W value becomes close to the reasonable range, and the autocorrelation is eliminated.

On this basis, a stationary test is conducted on the residual terms of the equation, inclu$\operatorname{ding} \varepsilon_{1}, \varepsilon_{2}$ and $\varepsilon_{3}$. If the residual terms are stationary, then there is a co-integration relationship between the amount of foreign direct investment in China and China's value of import and export with the US, that is, the estimation of the above equation exists; if the residual term has a unit root and is non-stationary, then there is no long-term co-integration relationship between foreign direct investment in China and China's import and export trade with the US, namely, the estimation of the above equation is wrong. The test results of the residual terms are shown in Table 2.

Table 2: Stationary Tests of Residuals of the Equation

\begin{tabular}{c|c|c|c|c|c|c}
\hline \multirow{2}{*}{ Variables } & \multirow{2}{*}{$\begin{array}{c}\text { ADF Test } \\
\text { Statistic }\end{array}$} & $\begin{array}{c}\mathbf{1} \% \text { criti- } \\
\text { cal value }\end{array}$ & $\begin{array}{c}\mathbf{5 \%} \text { criti- } \\
\text { cal value }\end{array}$ & $\begin{array}{c}\mathbf{1 0 \%} \text { criti- } \\
\text { cal value }\end{array}$ & $\begin{array}{c}\text { Statio- } \\
\text { narity }\end{array}$ & \multirow{2}{*}{ Type Test } \\
\hline$\varepsilon_{1}$ & -4.783978 & -2.632688 & -1.950687 & -1.611059 & stationary & $(0,0,0)$ \\
\hline$\varepsilon_{2}$ & -5.231943 & -2.632688 & -1.950687 & -1.611059 & stationary & $(0,0,0)$ \\
\hline$\varepsilon_{3}$ & -4.674098 & -2.632688 & -1.950687 & -1.611059 & stationary & $(0,0,0)$ \\
\hline
\end{tabular}

Source: The author obtained by using Eviews8.0 software analysis

It can be seen from Table 2 that at the significance level of $1 \%$, the residual terms of the three models pass the stationary test. Therefore, it can be considered that the residual terms of the three models are stationary, and there are co-integration relations among the three groups of variables, that is, there is a long-term stationary equilibrium relationship between foreign direct investment in China and the volume of Sino-US imports and exports. The models (8), (9) and (10) respectively represent the equilibrium relationship between foreign direct investment in China and China's export trade to the US, import trade and total volume of imports and exports between China and the US.

\section{Granger causality test}

The above test process shows that there is a long-term equilibrium relationship between foreign direct investment in China and China's export volume to the US, and between China's import volume to the US and China's total volume of imports and exports to the US, but it 
remains unclear whether this relationship can be called causality. Hence, the Granger causality test is carried out respectively on foreign direct investment in China, China's export volume to the US and China's total volume of imports and exports to the US, so as to test the existence of causality between the variables.

The following two regressions need to be carried out to do the Granger causality test:

$$
\begin{aligned}
& Y_{t}=\sum_{i=1}^{m} \alpha_{i} X_{t-i}+\sum_{i=1}^{m} \beta_{i} Y_{t-i}+\mu_{2 t} \\
& X_{t}=\sum_{i=1}^{m} \lambda_{i} Y_{t-i}+\sum_{i=1}^{m} \delta_{i} X_{t-i}+\mu_{2 t}
\end{aligned}
$$

The above two regressions are classified and discussed:

1. If the coefficient set with Y lagged term in (12) is statistically different from 0 , and the coefficient set with $\mathrm{X}$ lagged term in $(11)$ is statistically 0 , then there is a one-way causal relationship from $\mathrm{Y}$ to $\mathrm{X}$;

2. If the coefficient set with $\mathrm{X}$ lagged term in (11) is statistically different from 0 , and the coefficient set with Y lagged term in (12) is statistically 0, then there is a one-way causal relationship from $\mathrm{X}$ to $\mathrm{Y}$;

3. If the lagged coefficients of $\mathrm{X}$ and $\mathrm{Y}$ are statistically different from 0 in both regressions, then there is a two-way causal relationship between $\mathrm{X}$ and $\mathrm{Y}$;

4. If the lagged coefficients of $\mathrm{X}$ and $\mathrm{Y}$ are statistically 0 in both regressions, then there is no causal relationship between $\mathrm{X}$ and $\mathrm{Y}$.

The specific practice of the Granger causality test is to carry out constrained regression and unconstrained regression first, and then use the quadratic sum of the two residuals obtained to calculate the F-test statistic. The Granger causality test among foreign direct investment in China, Sino-US import and export volume and total trade volume is also conducted in Eviews8.0. The test results are shown in Table 3.

It can be concluded from the test results that, firstly, there is a one-way Granger causality between foreign direct investment in China and China's export trade with the US at the significance level of $10 \%$, that is, the increase of foreign direct investment in China expands China's export volume to the US, but the growth of China's export trade to the US does not Granger-cause foreign direct investment in China. Secondly, there is no Granger causality between foreign direct investment in China and China's import trade with the US, that is, the increase of China's import trade is not caused by the increase of foreign direct investment in China, and the increase of foreign direct investment in China is not the cause of the expansion of Sino-US import trade. Finally, there is no Granger causality between foreign direct investment in China and total volume of import and export trade between China and the US. 
Table 3: Granger Causality Test Results

\begin{tabular}{c|c|c|c}
\hline Null hypothesis & F test statistic & P value & Conclusion \\
\hline LNFDI does not Granger Cause LNEX & 2.88537 & 0.0540 & Rejected \\
\hline LNEX does not Granger Cause LNFDI & 0.21584 & 0.8845 & Received \\
\hline LNFDI does not Granger Cause LNIM & 0.47702 & 0.7009 & Received \\
\hline LNIM does not Granger Cause LNFDI & 1.17754 & 0.3367 & Received \\
\hline LNFDI does not Granger Cause LNTN & 1.01617 & 0.4009 & Received \\
\hline LNTN does not Granger Cause LNFDI & 0.45758 & 0.7142 & Received \\
\hline
\end{tabular}

Source: The author obtained by using Eviewes8.0 software analysis

Of course, the Granger causality test is not used to test causality in a real sense, but statistical causality. Therefore, the results of the Granger causality test can only support real causality but cannot be the most fundamental basis for affirming or denying the causality among variables.

\section{Analysis of test results}

Through the above test and analysis, it can be concluded that there is a long-term equilibrium relationship between foreign direct investment in China and the Sino-US import and export trade. Equations (8), (9) and (10) are co-integration equations which can respectively represent the relationship among foreign direct investment in China, the Sino-US import and export trade and total trade volume.

Co-integration equation (8) presents the regression results between foreign direct investment in China and China's export trade with the US. R2 of the equation is 0.99, and the coefficient of foreign direct investment in China is positive and passes the significance test at $1 \%$, indicating that the increase of foreign direct investment in China promotes the growth of China's export trade to the US. The coefficient of foreign direct investment in China is 0.37 , which means that every $1 \%$ increase in foreign direct investment in China can lead to $0.37 \%$ increase in China's export trade to the US. The equation also shows that there is a complementary relationship between foreign direct investment in China and China's export trade to the US.

Co-integration equation (9) shows the regression results between foreign direct investment in China and China's import trade to the US. R2 of the equation is 0.98 , the coefficient of foreign direct investment in China is positive, but the coefficient did not pass the significance test, suggesting that the increase of foreign direct investment in China has no obvious impact on China's import trade with the US. The analysis of equations (8) and (9) shows that foreign 
direct investment in China exerts a significantly positive impact on China's export trade to the US, but has a limited impact on China's import trade with the US, thereby increasing the trade surplus between China and the US.

Co-integration equation (10) presents the regression results between foreign direct investment in China and total import and export volume between China and the US. R2 of the equation is 0.99; the coefficient of foreign direct investment in China is positive and passes the significance test at $1 \%$, indicating that the increase of foreign direct investment in China promotes the development of Sino-US trade. The coefficient of foreign direct investment in China is 0.29 , suggesting that for every $1 \%$ increase in foreign direct investment in China, the import and export volume between China and the US will increase by $0.29 \%$, namely, the development of foreign direct investment in China plays a role in promoting the development of Sino-US trade.

The Granger causality test shows that there is a one-way Granger causality between the amount of foreign direct investment in China and China's export volume to the US at the $10 \%$ significance level. This indicates that the increase of foreign direct investment in China promotes the development of China's export trade to the US, thereby increasing China's trade surplus with the US.

\section{Elasticity ANALYSis}

To conduct a further study on the impact made on the Sino-US import and export trade by foreign direct investment in China, and also show a direct reflection of the impact that foreign direct investment in China exerts on Sino-US import and export trade, the paper expects to estimate the change in percentage of China's total volume of exports to the United States (Exp), China's total volume of imports to the United States (Imp), and the total volume of trade between China and the United States (Trade) when foreign direct investment in China (FDI) changes by $1 \%$. The elastic sequence can be measured based on historical data (APPENDIX A):

$$
\begin{aligned}
\varepsilon_{t}^{E x p} & =\frac{\left(E x p_{t}-E x p_{t-1}\right) / E x p_{t-1}}{\left(F D I_{t}-F D I_{t-1}\right) / F D I_{t-1}} \\
\varepsilon_{t}^{I m p} & =\frac{\left(I m p_{t}-I m p_{t-1}\right) / I m p_{t-1}}{\left(F D I_{t}-F D I_{t-1}\right) / F D I_{t-1}} \\
\varepsilon_{t}^{\text {Trade }}= & \frac{\left(\text { Trade }_{t}-\operatorname{Trade}_{t-1}\right) / \text { Trade }_{t-1}}{\left(F D I_{t}-F D I_{t-1}\right) / F D I_{t-1}}
\end{aligned}
$$

in which t represents time and $t=1,2 \ldots \mathrm{T}$, and the sample period lasts from 1983 to 2019 . 
Figure 1: Schematic diagram of elasticity coefficient sequences (\%)

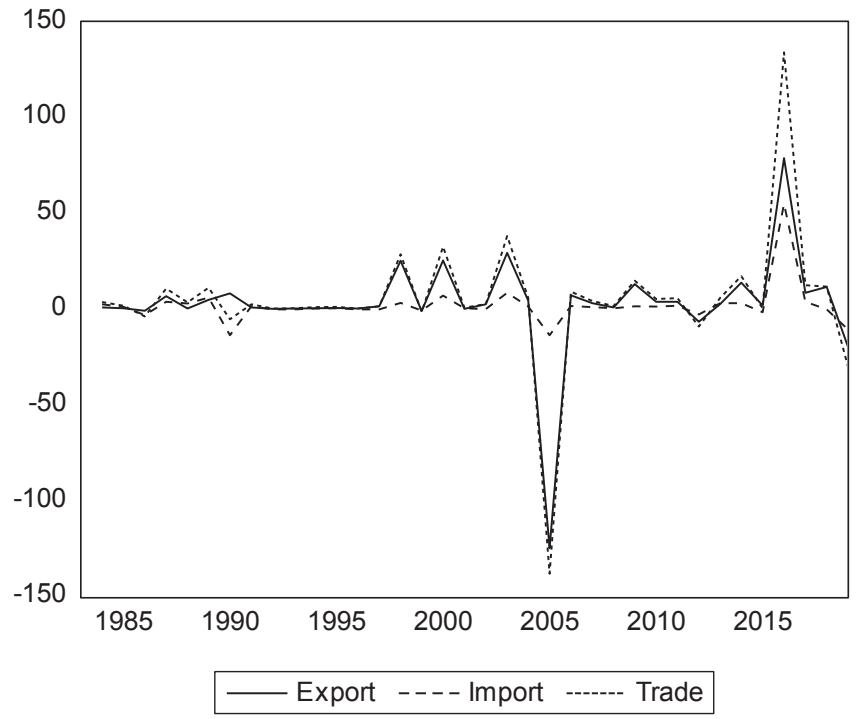

Source: The author obtained by using Eviews8.0 software analysis

The empirical analysis indicates that in the long run, foreign direct investment in China has a great impact on the Sino-US import and export trade.

\section{New Vicissitudes AND PROSPECT OF SinO-Us TRADE RELATIONS}

The Sino-US trade frictions starting in 2018 and the global pandemic that started in 2020 have had a certain impact on the development of transnational corporations in China. The Biden administration's trade policies with China have failed to bring a substantial improvement to the Sino-US trade relations.

Since 2019, the US Department of Commerce has added a number of Chinese corporations to the entity list for sanction, definitely restricting and blocking the development of Chinese corporations in the field of high technology. In 2020, the COVID-19 pandemic started to spread all over the world, and it may coexist with people for a long time in the future, which have subverted the production and lifestyle of global enterprises, institutions, organizations and individuals, and exerted a significantly adverse impact on the development of world economy and trade. The International Monetary Fund (IMF) also revised down the GDP growth rate of major economies in 2021, estimating that global foreign direct investment (FDI) will fall by 30\% 40\% from 2020 to 2021. (UNCTAD, 2020) Various uncertain factors in the international market are accelerating to reshape the new pattern of the world economy, and the strategic competition situation among major powers is becoming increasingly severe. 
Since influenced by the COVID-19 pandemic, global foreign direct investment suffered from a year-on-year decline of $49 \%$ in the first half of 2020, with a year-on-year decline of $75 \%$ in foreign direct investment flowing to developed economies and a year-on-year decline of $16 \%$ in foreign direct investment flowing to developing economies. In the first half of the year, foreign direct investment flowing into China fell by only $4 \%$ year on year, while by the third quarter of 2020, there was a year-on-year increase of $2.5 \%$ in foreign direct investment stocks that China had attracted. (UNCTAD, 2020)

US exports to China have not declined significantly due to the COVID-19 pandemic, while the actual trade volumes of Chinese export companies have not been achieved on account of the optimism derived from Biden's election victory.

In November 2020, Biden won the presidential election. Being an initiator of fair trade, the Biden team has also promised to revise existing trade policies. Trade policies with China remain basically unchanged, and there is a return to the TPP and the United States-Mexico-Canada Agreement again. There is a tendency to suppress in collaboration with allies rather than imposing additional tariffs by a single country. The crackdown on unfair competition and the infringement of intellectual property rights has been intensified. Penalties are continued to be imposed on countries engaging in unfair dumping and illegal subsidies, including tariff penalties and anti-dumping investigations. The Biden team will reduce trade friction on the whole, but not loosen trade penalties.

The value of US exports to China reached 14.723 billion US dollars in October 2020, an increase of 27.6\% over September. In November 2020, the value of US exports to China reached 15.712 billion US dollars, with an increase of $10.6 \%$ month on month. From September to November in 2020, with regard to the trade volume between China and the United States, the export volume of the United States continued to grow, while the export volume of China failed to have a sustained increase. (China Customs, 2020)

On the one hand, the United States is accelerating its policy of "Disengagement" from China, takes fields of high technology and areas with strong demand for security of supply and guarantee as the breakthrough points, and intervenes in the adjustment of the global value chain with various policies and initiatives, seeking to reduce the dependence of the global value chain on Chinese enterprises in an all-round way. In the future, suppressed by the political pressure of adjusting US policies for China, transnational corporations will inevitably restrain the level of investment, distribution and allocation in China while conducting a global deployment of advanced technologies and resources.

On the other hand, Chen Jiyong has considered that the attitude and measures of prevention and control when facing the COVID-19 pandemic have exacerbated the conflicts in the field of ideology. Based on the impact brought to the economy in the two countries by the pandemic, by analyzing the different measures and effects in the case of the pandemic, results have been concluded that affected by the overlapped influence brought by the Sino-US trade frictions and the pandemic, the subjective contradictions and objective differences between the United States and China, which are becoming constantly prominent, have led to the rebuilding of the bilateral economic and trade relations, and the bilateral strategic game is likely to further deepen. 
In short the expectation of "Disengagement" from China by the United States and the long-term prevention and control of the COVID-19 pandemic will reduce the willingness of transnational corporations to invest in China. The Biden administration's trade policies with China will remain largely unchanged, which will perpetuate the tensions in Sino-US trade relations.

\section{Conclusion}

The rapid growth of the Sino-US trade largely profit from the rapid advancement of foreign-invested enterprises in China. Our empirical analysis has found that in the long run, foreign direct investment in China has a great impact on the Sino-US import and export trade. By examining the correlation between the volume of foreign investment in China during 1983-2019 and the Sino-US import and export trade, a co-integration relationship between foreign direct investment in China and the Sino-US import and export trade has been revealed. Foreign direct investment in China has accelerated both import and export trade between China and the United States, that is, foreign direct investment in China has productive effects on the Sino-US import and export trade, among which the simulative effect of foreign direct investment in China on China's export trade to the United States is greater than that on China's import trade from the United States, resulting in the continuous expansion of China's trade surplus with the United States. From the analysis of this paper, we can conclude that foreign direct investment in China is an important factor which affects the Sino-US trade imbalance. Foreign direct investment in China affects Sino-US trade via the following ways: the number of foreign-funded enterprises is continuously increasing via foreign investment, and the large-scale import and export trade of foreign-funded enterprises results in the rapid expansion of China's import and export trade, while the United States is China's primary trading partner, thus it leads to a large-scale acceleration in Sino-US trade. Export trade grows faster than import trade, widening the gap between China and the United States. What needs attention is the fact that the expectation of "Disengagement" from China by the United States and the long-term prevention and control of the COVID-19 pandemic will reduce the willingness of transnational corporations to invest in China. The Biden administration's trade policies with China will remain largely unchanged, which will perpetuate the tensions in Sino-US trade relations.

\section{REFERENCES}

Burke J U. (2000): Investment in China worse trade deficit: U. S. firms Build export-oriented production base in China's low-wage, low labor-protection economy (DB /OL).

Chen Jiyong - Liu Wei (2006): A Study on the Issue of "Foreign Capital-Led Deficit" in US-China Trade, World Economy, 9

Chen Jiyong - Yang Ge (2020): The COVID-19 Pandemic and the Rebuilding of Sino-US Economic and Trade Relations, fournal of South China Normal University (Social Science Edition), (5):1G9.

Fu Qiang - Zhu Zhuying (2008a): The Influence of American Direct Investment in China on Sino-Us Trade Imbalance, International Trade Issues, 7, 77-81 
Fu Qiang - Zhu Zhuying (2008b): The Influence of US Direct Investment in China on Sino-US Trade Imbalance, International Trade Issues, 7

Gao Wenjuan (2009): Empirical analysis on the correlation between Sino-U.S. trade surplus and RMB exchange rate-Based on monthly data from 2005 to 2008, Fournal of Guang Xi University of economics and management, (4), pp.106-111

Gourinchas, P. O. - Rey, H. (2014): External adjushnent global imbalances valuation effects, In Handbook of International Economics, Vol. 4, 585-645.

Horstmann, I. J. - Markusen, J. R. (1987): Strategic investments and the development of multinationals [J]. International Economic Review, 28:109-121.

Kiyoshi Kojima (2000): The "flying geese" model of Asian economic development: origin, theoretical extensions, and regional policy implications, fournal of Asian Economics, 11:375-401.

Li Daokui - Li Danning (2006): Sino-US trade surplus: What's the root cause, International Economic Review, (5), p.1518.

Lipsey, R.E - Weiss, M.Y (1981): Foreign production and exports in manufacturing industries, Review of Economics and Statistics, 63, 488-494

Lipsey, R.E - Weiss, M.Y. (1984): Foreign production and exports of individual firms, Review of Economics and Statistics. vol. 66, issue 2, 304-08.

Lim, Sung Hoon - Moon Hwy-Chang (2001): Effects of Outward Foreign Direct Investment on Home Country Exports; the Case of Korean Firms. Multinational Business Review, Vol. 9, No. 1, 2001, pp. 42-49

McKinnon, R. (2001): The international dollar standard and the sustainability of the US current account deficit, Brookings Papers on Economic Activity 2001(1), 227-239.

Mundell, R. A. (1957): International trade and factor mobility, American Economic Review, 47, (3):321-335.

UNCTAD (2020): Investment Trends Monitor: Impact of the COVID - 19 Pandemic on Globe FDI and GVCs Updated Analysis https: / /unctad. org /en /Publications Library /diaeiainf2020d3_en

UNCTAD (2020): Global Foreign Direct Investment Falls 49\% Outlook Remains Negative,27 October 2020 https: / / unctad. org /news /global-foreign-direct-investment-falls -49-outlook-remains - negative

Phoenix Finance (2019): In 2018, China's trade surplus with the United States increased by $17.2 \%$ years on year to US $\$ 323.32$ billion, January 14. https://finance.ifeng.com/c/7jS9DASss5X

Qian J. (2019): Chinese economy 2018: transforming economic structures and stabilizing growth, East Asian Policy, 11 (1) World Scientific Publishing Co. Pte. Ltd., vol. 11(01), p. 14-32.

Qu Xiaosheng (2006): Study on the relationship between the US trade deficit with China and RMB exchange rate, fournal of south China university of technology (Social science edition), (8), pp.38-40

Tian Yinhua - Zhu Wenwei (2005): A Co-integration Analysis on the Impact of American Direct Investment on Sino-US Trade Contemporary Finance \& Economics, 10.

Wang Hongliang - Xu Xia (2003): A Study on the Relationship between Japan's Trade with China and the Direct Investment, World Economy, 8

Website of China Statistics Bureau http://www.gov.cn/xinwen/2020-01/17/content_5470113.htm

Wind- Economic Database, https://www.wind.com.cn/NewSite/edb.html

Xiaming Liu - Chengang Wang - Yingqi Wei (2001): Causal Links between Foreign Direct Investment and Trade in China, China Economic Review, (12):190-202.

Xiang Weixing (2018): The History of Sino-US Trade A Study on Sino-US Economic Interdependence and Its Asymmetry, Beijing: Social Sciences Academic Press (China), Preface

Zhu Caihua (2010): Sino-US Mutual Direct Investment: Current Situation, Obstacles and Policy Recommendations, International Economic Cooperation, (2):4-12.

Zhao Beiwen (2009): The Impact of FDI on US-China Trade Deficit in the Context of Trade and Investment Integration: Theoretical Analysis and Empirical Test [J. International Trade Issues, 10. 


\section{APPENDIX A}

Amount of Foreign Direct Investment in China and the Sino-US Trade Volume from 1983 to 2019

Unit: US\$100 million

\begin{tabular}{|c|c|c|c|c|}
\hline Year & $\begin{array}{c}\text { Amount of } \\
\text { foreign direct } \\
\text { investment in } \\
\text { China }\end{array}$ & $\begin{array}{c}\text { China's export } \\
\text { volume to the US }\end{array}$ & $\begin{array}{c}\text { China's import } \\
\text { volume from the } \\
\text { US }\end{array}$ & $\begin{array}{l}\text { Total Sino-US } \\
\text { trade volume }\end{array}$ \\
\hline 1983 & 9.16 & 17.10 & 23.20 & 40.30 \\
\hline 1984 & 14.19 & 23.00 & 36.60 & 59.60 \\
\hline 1985 & 19.56 & 26.50 & 43.70 & 70.20 \\
\hline 1986 & 22.44 & 24.70 & 35.30 & 60.00 \\
\hline 1987 & 23.14 & 29.60 & 38.10 & 67.70 \\
\hline 1988 & 31.94 & 33.80 & 66.30 & 100.10 \\
\hline 1989 & 33.92 & 43.90 & 78.60 & 122.50 \\
\hline 1990 & 34.87 & 51.90 & 65.80 & 117.70 \\
\hline 1991 & 43.66 & 61.90 & 80.10 & 142.00 \\
\hline 1992 & 110.08 & 85.04 & 89.01 & 174.05 \\
\hline 1993 & 275.15 & 169.64 & 106.88 & 276.52 \\
\hline 1994 & 337.67 & 214.61 & 138.94 & 353.55 \\
\hline 1995 & 375.21 & 247.29 & 161.23 & 408.52 \\
\hline 1996 & 417.26 & 267.08 & 161.79 & 428.87 \\
\hline 1997 & 452.57 & 327.18 & 162.90 & 490.08 \\
\hline 1998 & 454.63 & 379.65 & 169.97 & 549.62 \\
\hline 1999 & 403.19 & 420.18 & 194.86 & 615.04 \\
\hline 2000 & 407.15 & 521.42 & 223.65 & 745.07 \\
\hline 2001 & 468.78 & 543.19 & 262.04 & 805.23 \\
\hline 2002 & 527.43 & 699.59 & 272.28 & 971.87 \\
\hline 2003 & 535.05 & 925.10 & 338.83 & 1263.93 \\
\hline 2004 & 606.30 & 1249.73 & 446.53 & 1696.26 \\
\hline 2005 & 603.25 & 1629.39 & 487.35 & 2116.74 \\
\hline 2006 & 658.21 & 2035.16 & 592.23 & 2627.39 \\
\hline 2007 & 747.68 & 2327.61 & 698.61 & 3026.22 \\
\hline 2008 & 923.95 & 2523.27 & 814.97 & 3338.24 \\
\hline 2009 & 900.33 & 2209.05 & 774.60 & 2983.65 \\
\hline 2010 & 1057.35 & 2833.75 & 1020.60 & 3854.35 \\
\hline 2011 & 1160.11 & 3245.65 & 1221.44 & 4467.09 \\
\hline
\end{tabular}




\begin{tabular}{c|c|c|c|c}
\hline Year & $\begin{array}{c}\text { Amount of } \\
\text { foreign direct } \\
\text { investment in } \\
\text { Ghina }\end{array}$ & $\begin{array}{c}\text { China's export } \\
\text { volume to the US }\end{array}$ & $\begin{array}{c}\text { Ghina's import } \\
\text { volume from the } \\
\text { US }\end{array}$ & $\begin{array}{c}\text { Total Sino-US } \\
\text { trade volume }\end{array}$ \\
\hline 2012 & 1117.16 & 3520.00 & 1328.78 & 4848.78 \\
\hline 2013 & 1175.86 & 3684.81 & 1525.52 & 5210.33 \\
\hline 2014 & 1195.62 & 3961.47 & 1591.87 & 5553.35 \\
\hline 2015 & 1262.67 & 4101.45 & 1497.81 & 5599.26 \\
\hline 2016 & 1260.01 & 3891.13 & 1351.24 & 5242.37 \\
\hline 2017 & 1310.35 & 4331.46 & 1551.77 & 5883.24 \\
\hline 2018 & 1349.66 & 4798.12 & 1553.66 & 6351.77 \\
\hline 2019 & 1381.35 & 4179.36 & 1223.39 & 5402.75 \\
\hline
\end{tabular}

Note: The data is from Wind and the National Bureau of Statistics of China.

\section{APPENDIX B}

Logarithmic Values of the Figures in Appendix A

\begin{tabular}{|c|c|c|c|c|}
\hline Year & $\begin{array}{l}\text { Amount of } \\
\text { foreign direct } \\
\text { investment in } \\
\text { China }\end{array}$ & $\begin{array}{l}\text { China's export } \\
\text { volume to the US }\end{array}$ & $\begin{array}{l}\text { China's import } \\
\text { volume from the } \\
\text { US }\end{array}$ & $\begin{array}{l}\text { Total Sino-US } \\
\text { trade volume }\end{array}$ \\
\hline 1983 & 2.2148025 & 2.8390785 & 3.1441523 & 3.6963515 \\
\hline 1984 & 2.6524318 & 3.1354942 & 3.6000482 & 4.0876556 \\
\hline 1985 & 2.9734867 & 3.2771447 & 3.7773481 & 4.2513483 \\
\hline 1986 & 3.1108451 & 3.2068032 & 3.563883 & 4.0943446 \\
\hline 1987 & 3.1415627 & 3.3877744 & 3.6402143 & 4.2150862 \\
\hline 1988 & 3.4638591 & 3.5204608 & 4.1941899 & 4.6061697 \\
\hline 1989 & 3.5240048 & 3.7819143 & 4.3643717 & 4.808111 \\
\hline 1990 & 3.5516269 & 3.9493188 & 4.1866198 & 4.768139 \\
\hline 1991 & 3.7764324 & 4.1255202 & 4.3832759 & 4.9558271 \\
\hline 1992 & 4.7012074 & 4.4431217 & 4.4887487 & 5.1593426 \\
\hline 1993 & 5.6173164 & 5.1336785 & 4.6717067 & 5.6222832 \\
\hline 1994 & 5.8220691 & 5.3688224 & 4.9340422 & 5.8680249 \\
\hline 1995 & 5.9274859 & 5.5105513 & 5.0828298 & 6.0125337 \\
\hline 1996 & 6.0337095 & 5.5875515 & 5.0862776 & 6.0611477 \\
\hline 1997 & 6.1149424 & 5.7905221 & 5.0931113 & 6.194568 \\
\hline 1998 & 6.1194839 & 5.9392491 & 5.1356187 & 6.3092256 \\
\hline 1999 & 5.9994079 & 6.040685 & 5.2722976 & 6.4216937 \\
\hline 2000 & 6.0091817 & 6.2565559 & 5.4100647 & 6.6134729 \\
\hline
\end{tabular}


Fiandong Shi: Foreign Direct Investment in China and the Sino-US Trade Imbalance

\begin{tabular}{|c|c|c|c|c|}
\hline Year & $\begin{array}{c}\text { Amount of } \\
\text { foreign direct } \\
\text { investment in } \\
\text { China }\end{array}$ & $\begin{array}{c}\text { China's export } \\
\text { volume to the US }\end{array}$ & $\begin{array}{l}\text { China's import } \\
\text { volume from the } \\
\text { US }\end{array}$ & $\begin{array}{l}\text { Total Sino-US } \\
\text { trade volume }\end{array}$ \\
\hline 2001 & 6.1501336 & 6.2974575 & 5.5684816 & 6.6911218 \\
\hline 2002 & 6.2680162 & 6.5505002 & 5.6068273 & 6.8792252 \\
\hline 2003 & 6.2823602 & 6.8299034 & 5.8254974 & 7.1419821 \\
\hline 2004 & 6.4073749 & 7.1306864 & 6.101499 & 7.4361818 \\
\hline 2005 & 6.4023317 & 7.3959593 & 6.1889821 & 7.657631 \\
\hline 2006 & 6.489524 & 7.6183311 & 6.3838926 & 7.8737468 \\
\hline 2007 & 6.6169751 & 7.7525987 & 6.5490866 & 8.0150693 \\
\hline 2008 & 6.828658 & 7.833312 & 6.7031479 & 8.113199 \\
\hline 2009 & 6.8027614 & 7.700317 & 6.652351 & 8.0009031 \\
\hline 2010 & 6.9635211 & 7.9493557 & 6.9281504 & 8.2569585 \\
\hline 2011 & 7.0562701 & 8.0850701 & 7.107789 & 8.4044927 \\
\hline 2012 & 7.018545 & 8.1662159 & 7.1920187 & 8.4864828 \\
\hline 2013 & 7.0697551 & 8.2119733 & 7.3300922 & 8.5583983 \\
\hline 2014 & 7.0864202 & 8.2843715 & 7.3726666 & 8.6221561 \\
\hline 2015 & 7.1409838 & 8.3190963 & 7.3117589 & 8.6303899 \\
\hline 2016 & 7.1388749 & 8.2664537 & 7.2087801 & 8.5645286 \\
\hline 2017 & 7.1780496 & 8.373661 & 7.3471533 & 8.6798625 \\
\hline 2018 & 7.207608 & 8.4759787 & 7.3483678 & 8.7564896 \\
\hline 2019 & 7.2308138 & 8.3379127 & 7.1093802 & 8.5946627 \\
\hline
\end{tabular}

Note: The values are calculated by Excel, where LNFDI is the logarithm of foreign direct investment in China; LNEX is the logarithm of China's export volume to the US; LNIM is the logarithm of China's import volume from the US; LNTN is the logarithm of the total Sino-US trade volume. 